\title{
Geology
}

\section{Plume-lithosphere interaction in generation of the Emeishan flood basalts at the Permian-Triassic boundary}

Sun-Lin Chung and Bor-ming Jahn

Geology 1995;23;889-892

doi: 10.1130/0091-7613(1995)023<0889:PLIIGO>2.3.CO;2

\section{Email alerting services}

\section{Subscribe}

Permission request click www.gsapubs.org/cgi/alerts to receive free e-mail alerts when new articles cite this article

click www.gsapubs.org/subscriptions/ to subscribe to Geology

click http://www.geosociety.org/pubs/copyrt.htm\#gsa to contact GSA

Copyright not claimed on content prepared wholly by U.S. government employees within scope of their employment. Individual scientists are hereby granted permission, without fees or further requests to GSA, to use a single figure, a single table, and/or a brief paragraph of text in subsequent works and to make unlimited copies of items in GSA's journals for noncommercial use in classrooms to further education and science. This file may not be posted to any Web site, but authors may post the abstracts only of their articles on their own or their organization's Web site providing the posting includes a reference to the article's full citation. GSA provides this and other forums for the presentation of diverse opinions and positions by scientists worldwide, regardless of their race, citizenship, gender, religion, or political viewpoint. Opinions presented in this publication do not reflect official positions of the Society.

\section{Notes}




\title{
Plume-lithosphere interaction in generation of the Emeishan flood basalts at the Permian-Triassic boundary
}

\author{
Sun-Lin Chung Department of Geology, National Taiwan University, Taipei, Taiwan, Republic of China \\ Bor-ming Jahn Géosciences Rennes, Université de Rennes 1, F-35042 Rennes Cedex, France
}

\section{ABSTRACT}

The Emeishan flood volcanism that erupted at Permian-Triassic boundary time produced a large igneous province of at least $2.5 \times 10^{5} \mathrm{~km}^{2}$ in the western margin of the Yangtze craton, southwestern China. The volcanic successions, suggested to have resulted from a starting mantle plume, comprise thick piles of basaltic flows and subordinate picrites and pyroclastics. The picrites, which have high magnesian contents $(\mathrm{MgO} \simeq 20-16$ wt\%), variable degrees of light rare earth element enrichment $\left[(\mathbf{C e} / \mathbf{Y b})_{N} \simeq 4-25\right]$ and heterogeneous isotope ratios $\left[\varepsilon_{\mathrm{Nd}}(T) \simeq+4\right.$ to -4$]$, are proposed to have been generated by mixing between the dominant plume-derived magmas and small amounts of lamproitic liquids from the continental lithospheric mantle.

\section{INTRODUCTION}

Large igneous provinces (LIPs; Coffin and Eldholm, 1994), characterized by voluminous volcanic sequences erupted in a short period of time, are believed to be linked genetically with mantle plume activities (Richards et al., 1989; Campbell and Griffiths, 1990). Examples of LIPs include continental flood basalt provinces and oceanic plateaus. Continental flood basalts commonly have trace element and radiogenic isotope compositions that are outside the range of plume sources defined by oceanic island basalts. In cases where crustal contamination can be excluded, many studies suggest that the lithospheric mantle plays a significant role, in addition to plume materials from the deep mantle, in continental flood volcanism (e.g., Ellam and Cox, 1991; Saunders et al., 1992). However, arguments against an important lithospheric mantle contribution (McKenzie and Bickle, 1988; Arndt and Christensen, 1992) have also been advocated.

The relation between the composition of mantle melts, degree of partial melting, and temperature of mantle sources has been much discussed (cf. McKenzie and Bickle, 1988). Generally, in areas where a hot mantle plume rises, as occurs in many LIPs, the degree of melting would be greater and the parental melt can be picritic. Such highmagnesian liquids could not only provide constraints on defining geochemical characteristics of the plume source region (Campbell and Griffiths, 1990), but could also be used to evaluate the role of plume-lithosphere interaction (Ellam et al., 1992; Saunders et al., 1992).

In this paper we report new geochemical and $\mathrm{Sr}-\mathrm{Nd}$ isotope data of picrites from the Emeishan flood basalt province, an important LIP in southwestern China not yet well recognized by the international geological erogeneous enrichment in the incompatible trace elements, similar to those observed in the Nuanetsi picrites of the Karoo province (South Africa) (Ellam and Cox, 1991). We community. These high-Mg rocks show het- use these data to demonstrate that the lithospheric mantle has played a key role in the generation of Emeishan picritic magmas, which are believed to be parental to the voluminous basaltic rocks related to a mantle plume activity.

\section{BACKGROUND}

In China, the Emeishan basalt is generally referred to the Permian-Triassic massive volcanic successions in the western margin of the Yangtze craton. These volcanic rocks unconformably overlie early Late Permian carbonate formations (i.e., the Maokou Limestone) and are covered by Triassic sedimentary sequences. They crop out dis-

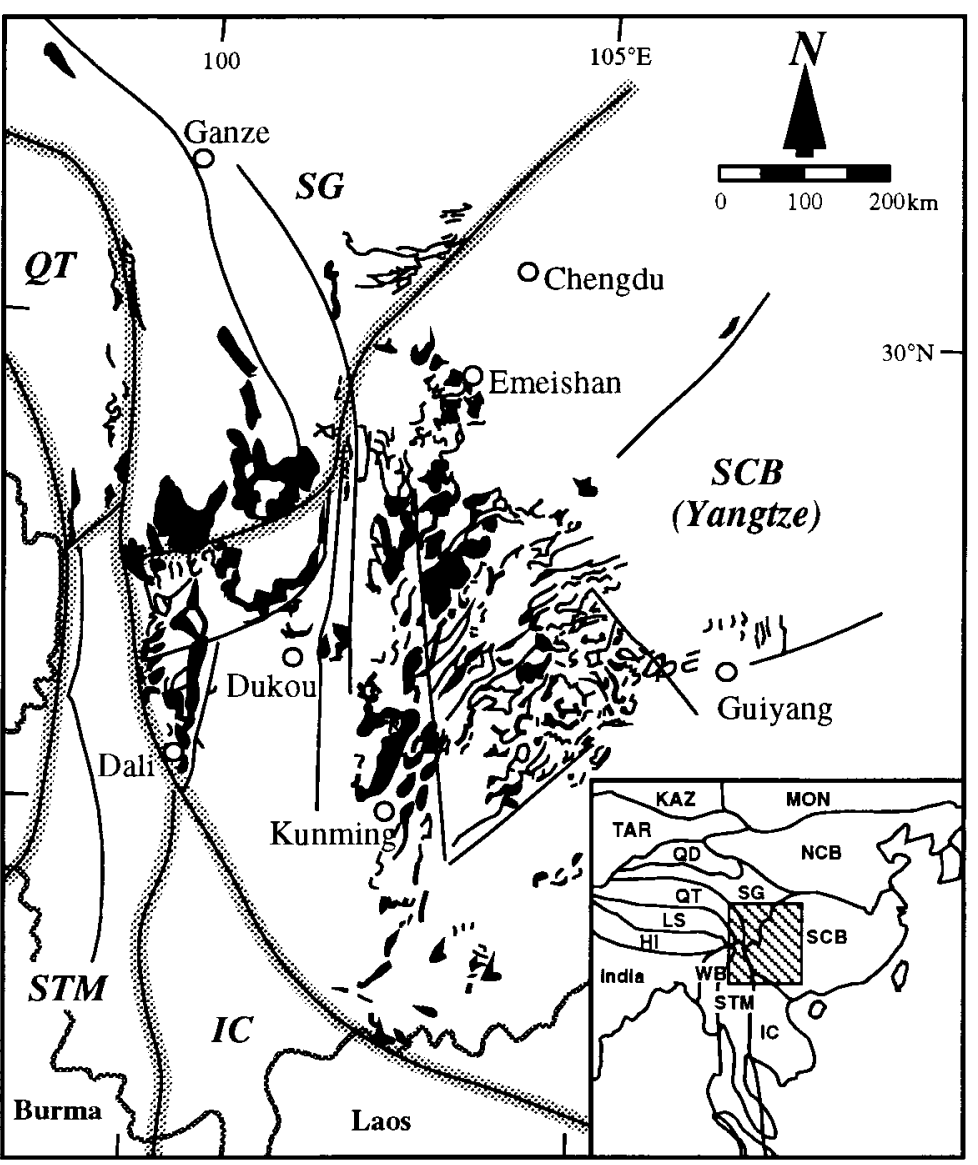

Figure 1. Generalized map showing outcrops of Emeishan flood basalts (black areas) as well as contemporaneous massive basalts (also in black) emplaced in Songpan-Ganze and Qiangtang terranes. Lines mark boundaries of and inset illustrates distribution of major terranes in China and adjacent regions (Huang et al., 1992). HI = Himalaya; IC = Indochina; KAZ = Kazakhstan; LS = Lhasa; MON = Mongolia; NCB = North China block; QD = Qaidam; QT = Qiangtang; SCB = South China block; SG = Songpan-Ganze accretionary complex; STM = Shan-Thai-Malay; TAR = Tarim; WB = West Burma. 
TABLE 1. CHEMICAL AND ISOTOPIC COMPOSITIONS OF EMEISHAN PICRITES

\begin{tabular}{|c|c|c|c|c|c|c|c|}
\hline & EM-55 & EM-56 & EM-57 & EM-58 & EM-70 & EM-79 & EM-83 \\
\hline \multicolumn{8}{|c|}{ Major elements (wt\%) } \\
\hline $\mathrm{SiO}_{2}$ & 45.02 & 44.23 & 45.30 & 45.32 & 45.18 & 43.90 & 44.28 \\
\hline $\mathrm{TiO}_{2}$ & 2.77 & 2.46 & 2.61 & 2.60 & 2.14 & 1.32 & 1.77 \\
\hline $\mathrm{Al}_{2} \mathrm{O}_{3}$ & 7.82 & 7.42 & 7.66 & 7.62 & 6.41 & 7.73 & 9.25 \\
\hline $\mathrm{Fe}_{2} \mathrm{O}_{3} *$ & 13.64 & 13.25 & 13.64 & 13.51 & 12.21 & 13.75 & 12.78 \\
\hline $\mathrm{MnO}$ & 0.19 & 0.18 & 0.19 & 0.18 & 0.16 & 0.20 & 0.17 \\
\hline $\mathrm{MgO}$ & 16.56 & 18.51 & 17.79 & 17.83 & 19.78 & 19.19 & 15.98 \\
\hline $\mathrm{CaO}$ & 8.88 & 7.98 & 8.59 & 8.50 & 9.04 & 10.30 & 9.71 \\
\hline $\mathrm{Na}_{2} \mathrm{O}$ & 1.38 & 1.07 & 1.50 & 1.27 & 1.05 & 0.79 & 1.21 \\
\hline $\mathrm{K}_{2} \mathrm{O}$ & 0.90 & 0.97 & 0.84 & 0.97 & 0.12 & 0.74 & 0.44 \\
\hline $\mathrm{P}_{2} \mathrm{O}_{5}$ & 0.23 & 0.22 & 0.22 & 0.22 & 0.24 & 0.09 & 0.15 \\
\hline L.O.I. & 2.40 & 2.71 & 1.56 & 1.87 & 2.49 & 0.49 & 2.67 \\
\hline Mg number* & 72.8 & 75.5 & 74.2 & 74.4 & 78.1 & 75.4 & 73.3 \\
\hline \multicolumn{8}{|c|}{ Trace elements (ppm) } \\
\hline $\mathrm{Rb}$ & 19 & 22 & 17 & 18 & 2 & 21 & 12 \\
\hline $\mathrm{Ba}$ & 336 & 927 & 279 & 459 & 45 & 113 & 172 \\
\hline Th & 3.9 & 2.8 & 3.3 & 3.1 & 5.3 & 0.7 & 1.7 \\
\hline $\mathbf{U}$ & 0.7 & 0.5 & 0.7 & 0.6 & 1.1 & 0.2 & 0.3 \\
\hline $\mathrm{Nb}$ & 28 & 22 & 27 & 27 & 34 & 9 & 14 \\
\hline $\mathrm{Ta}$ & 1.9 & 1.2 & 1.7 & 1.6 & 1.9 & 0.6 & 0.6 \\
\hline $\mathrm{Sr}$ & 429 & 367 & 454 & 444 & 229 & 231 & 148 \\
\hline $\mathrm{Zr}$ & 168 & 151 & 161 & 162 & 181 & 72 & 112 \\
\hline Hf & 4.4 & 4.3 & 4.4 & 4.2 & 4.9 & 2.1 & 2.6 \\
\hline Y & 22 & 21 & 21 & 21 & 15 & 13 & 21 \\
\hline $\mathrm{V}$ & 302 & 241 & 286 & 284 & 226 & 258 & 309 \\
\hline $\mathrm{Ga}$ & 16 & 15 & 15 & 16 & 13 & 13 & 15 \\
\hline $\mathrm{Cu}$ & 141 & 117 & 126 & 135 & 103 & 145 & 197 \\
\hline $\mathrm{Zn}$ & 100 & 94 & 100 & 100 & 74 & 110 & 95 \\
\hline $\mathrm{Sc}$ & 28 & n.d. & 26 & 27 & n.d. & n.d. & n.d. \\
\hline Co & 69 & 77 & 74 & 73 & 73 & 82 & 72 \\
\hline $\mathrm{Ni}$ & 713 & 901 & 795 & 784 & 1004 & 794 & 828 \\
\hline $\mathrm{Cr}$ & 1344 & 1457 & 1534 & 1436 & 1906 & 1590 & 1717 \\
\hline $\mathrm{La}$ & 31.1 & 25.7 & 27.6 & 26.9 & 42.0 & 8.4 & 15.3 \\
\hline $\mathrm{Ce}$ & 64.2 & 55.2 & 58.3 & 56.6 & 87.5 & 19.2 & 32.3 \\
\hline Nd & 32.2 & $28.22 \dagger$ & $30.36 \dagger$ & $30.33 \dagger$ & $41.11 \dagger$ & $11.53 \dagger$ & $19.43 \dagger$ \\
\hline $\mathrm{Sm}$ & 6.93 & $5.698 \dagger$ & $6.202 \dagger$ & $6.223 \dagger$ & $7.356 \dagger$ & $2.819 \dagger$ & $4.369 \dagger$ \\
\hline $\mathrm{Eu}$ & 1.98 & 1.75 & 1.89 & 1.86 & 1.74 & 0.85 & 1.25 \\
\hline $\mathrm{Tb}$ & 0.87 & 0.76 & 0.81 & 0.79 & 0.90 & 0.51 & 0.57 \\
\hline $\mathrm{Yb}$ & 1.62 & 1.30 & 1.60 & 1.53 & 0.98 & 1.40 & 1.50 \\
\hline $\mathrm{Lu}$ & 0.21 & 0.20 & 0.17 & 0.19 & 0.13 & 0.13 & 0.20 \\
\hline \multicolumn{8}{|l|}{ Isotope ratios } \\
\hline${ }^{87} \mathrm{Sr} /{ }^{86} \mathrm{Sr}$ & 0.70497 & 0.70501 & 0.70480 & 0.70488 & 0.70647 & 0.70586 & 0.70541 \\
\hline $\mathrm{I}_{\mathrm{Sr}}(250 \mathrm{Ma})$ & 0.70451 & 0.70439 & 0.70441 & 0.70446 & 0.70638 & 0.70492 & 0.70458 \\
\hline${ }^{143} \mathrm{Nd} /{ }^{144} \mathrm{Nd}$ & 0.51260 & 0.51261 & 0.51259 & 0.51267 & 0.51229 & 0.51276 & 0.51268 \\
\hline$\varepsilon_{\mathrm{Nd}}(250 \mathrm{Ma})$ & 1.4 & 1.7 & 1.5 & 2.8 & -4.0 & 4.0 & 2.8 \\
\hline \multicolumn{8}{|c|}{$\begin{array}{l}\text { Note: Elemental determinations, except where marked, were made by XRF at Université de } \\
\text { Rennes and by INAA at National Taiwan University. The analytical uncertainties are generally } \\
\text { better than } 5 \% \text { for the XRF and 5-15\% for the INAA. Isotope measurements were made by a } \\
\text { Finnigan MAT262 at Université de Rennes. The two standard errors are less than } 0.00001 \text { for } \\
\text { both } \mathrm{Sr} \text { and } \mathrm{Nd} \text { isotope ratios, which are reported relative to }{ }^{87} \mathrm{Sr} /{ }^{86} \mathrm{Sr}=0.71020 \text { for NBS } 987 \\
\text { and }{ }^{143} \mathrm{Nd} /{ }^{144} \mathrm{Nd}=0.511860 \text { for } \mathrm{La} \text { Jolla, respectively. n.d. }=\text { not determined. } \\
{ }^{*} \text { Total iron as } \mathrm{Fe}_{2} \mathrm{O}_{3} ; \mathrm{Mg} \text { number }=\text { molecular proportion of } \mathrm{MgO} /(\mathrm{MgO}+\mathrm{FeO}) \text {, calculated by } \\
\text { assuming } \mathrm{FeO}=0.9 \times \text { total FeO. } \\
+ \text { Concentrations determined by isotope dilution at Université de Rennes. }\end{array}$} \\
\hline
\end{tabular}

persed in a rhomb-shaped province of $\sim 500$ $\times 500 \mathrm{~km}^{2}$ (Fig. 1) via block faulting probably active since the Early Jurassic, a process that also exposed the associated intrusive rocks in many localities. The thickness of the entire volcanic sequence varies from $\sim 5 \mathrm{~km}$ in the west to a few hundred metres in the east. It consists mainly of basaltic lavas and subordinate amounts of picrites and pyroclastic rocks. In addition, thick flows and tuffs of trachyte and rhyolite composition sive volcanic successions may have been emplaced in a short time period, similar to the Siberian Traps at $\sim 250 \mathrm{Ma}$ (Campbell et al., 1992), a time coincident with a major extinction event. We (Chung and Jahn, 1993) therefore proposed that the Emeishan flood basalt province resulted from a starting mantle plume (Campbell and Griffiths, 1990) in Permian-Triassic time, when the South China block was drifting near the equator (Huang et al., 1992).

\section{EMEISHAN PICRITES}

In the Emeishan province, mafic volcanic rocks show a wide range of major element abundances $\left(\mathrm{SiO}_{2} \simeq 43-56 \mathrm{wt} \% ; \mathrm{MgO} \simeq\right.$ 4-11 wt $\%$ ) and various degrees of enrichment in the incompatible trace elements (Huang, 1986). Most basalts are evolved, with $\mathrm{MgO}<7 \mathrm{wt} \%$, and are believed to be differentiated from picritic parental magmas. The picrites studied in this paper were collected in two locations near the Dukou area (Fig. 1), where the volcanic sequence is 1-2 km thick. Samples of the first location (EM-55 to EM-58) are from different levels of a 50-m-thick flow; those of the second location (EM-70, EM-79, and EM-83) are from three separate thin flows intercalated with basaltic lavas. As shown in Table 1, all these rocks have high magnesian $(\mathrm{MgO} \simeq$ $20-16 \mathrm{wt} \%)$ and low aluminum $\left(\mathrm{Al}_{2} \mathrm{O}_{3} \simeq\right.$ 6.4-9.3 wt\%) and calcium $(\mathrm{CaO} \simeq 8.0-10.3$ wt $\%$ ) contents. They are marked by variable degrees of enrichment in the very incompatible trace elements, a characteristic shared with the associated basalts. In addition, the increase of light rare earth element (REE) enrichment $\left[\mathrm{La}_{\mathrm{N}} \simeq 12-60,(\mathrm{Ce} / \mathrm{Yb})_{\mathrm{N}} \simeq\right.$ 4-25; normalized to primitive-mantle values of Sun and McDonough, 1989] is coupled with a decrease of heavy REE abundances $\left(\mathrm{Yb}_{\mathrm{N}} \simeq 3-2\right)$ and a slight $\mathrm{Nb}-\mathrm{Ta}$ depletion [e.g., $(\mathrm{Nb} / \mathrm{La})_{\mathrm{N}} \simeq 1.03-0.78$ ]. Some mobile elements, such as $\mathrm{Rb}, \mathrm{Ba}$, and $\mathrm{K}$, however, may have been affected by secondary alteration processes. For example, sample EM-70 displays unusually low abundances of these elements but is highly enriched in the light REEs and other very incompatible elements.

The initial $\varepsilon_{\mathrm{Nd}}$ values and ${ }^{87} \mathrm{Sr} /{ }^{86} \mathrm{Sr}$ ratios of the picrites, i.e., $\varepsilon_{\mathrm{Nd}}(\mathrm{T})$ and $\left({ }^{87} \mathrm{Sr} /{ }^{86} \mathrm{Sr}\right)_{i}$, calculated for $250 \mathrm{Ma}$, range from +4 to -4 and 0.7044 to 0.7064 , respectively (Table 1 ). They plot inside the field defined by Emeishan basalts, a field that is grossly comparable to oceanic island basalts (Fig. 2A). The Emeishan field is more restricted than fields for the Siberian Traps (Wooden et al., 1993) and other continental flood basalts worldwide. We prefer to use only $\varepsilon_{\mathrm{Nd}}(\mathrm{T})$ values rather than a combination with $\left({ }^{87} \mathrm{Sr} /{ }^{86} \mathrm{Sr}\right)_{i}$ 

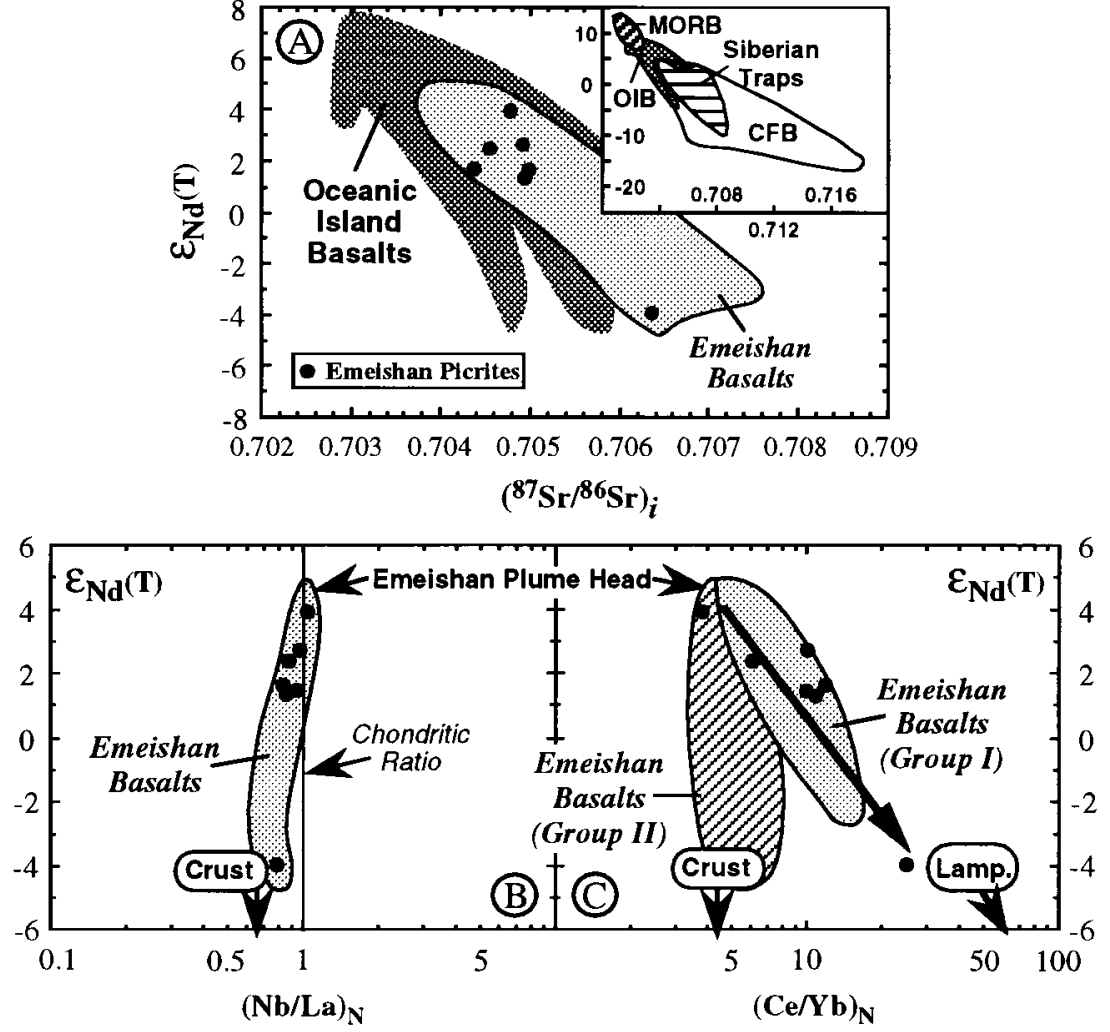

Figure 2. Plots of $\varepsilon_{N d}(T)$ vs. (A) $\left({ }^{87} \mathrm{Sr} /{ }^{86} \mathrm{Sr}\right)_{i}$, (B) $(\mathrm{Nb} / \mathrm{La})_{N}$, and (C) $(\mathrm{Ce} / \mathrm{Yb})_{\mathrm{N}}$ for Emeishan picrites. In A, fields for Emeishan basalts, oceanic island basalts (OIB), Siberian basalts, and continental flood basalts (CFB) worldwide (inset; Wooden et al., 1993) are compared (MORB = mid-ocean ridge basalt). B and C: Both suggested contaminants of Emeishan basalts, i.e., upper continental crust (Taylor and McLennan, 1985) and olivine lamproites (Jaques et al., 1989), have $\varepsilon_{\mathrm{Nd}}$ values that would be far below lower margin of diagram, as indicated by arrows. Note that two subgroups of basalts can be distinguished, and picrites are in group I trend, marked by distinctly elevated $\mathrm{Ce} / \mathrm{Yb}$ ratios.

ratios in our petrogenetic discussion, because the latter might have been more or less shifted by secondary alteration. For the following reasons all these picrites are regarded as primary mantle melts. (1) Some samples (e.g., EM-70 and EM-83) have finegrained textures, with euhedral, isolated, simple olivine phenocrysts; no large olivine crystals are observed. In other samples, with large olivine crystals (EM-55 and EM-56), the rather homogeneous core compositions $\left(\mathrm{Fo}_{87}-\mathrm{Fo}_{91}\right)$ argue for their chemical equilibrium with the whole-rock $\mathrm{Mg}$ numbers (72.8-78.1; Table 1), according to the $\mathrm{Mg}-\mathrm{Fe}$ exchange coefficient between olivine and melt (Roeder and Emslie, 1970). (2) There is a good correlation between isotope ratios and trace element systematics for the picrites, as shown in the $\varepsilon_{\mathrm{Nd}}(\mathrm{T}) \mathrm{vs}$. $(\mathrm{Ce} / \mathrm{Yb})_{\mathrm{N}}$ plot (Fig. 2C). The picrite with the least light-REE enrichment (EM-79) shows the highest $\varepsilon_{\mathrm{Nd}}(\mathrm{T})$ value and does not display $\mathrm{Nb}$-Ta depletion. By contrast, the one with the greatest light-REE enrichment (EM-70) has the lowest $\varepsilon_{\mathrm{Nd}}(\mathrm{T})$ value and a negative $\mathrm{Nb}$-Ta anomaly (Fig. 2B). This is more likely caused by binary magma mixing than by olivine accumulation (see discussion below).

\section{DISCUSSION}

The Emeishan basalts can be divided into two subgroups, each with specific elemental and isotopic features. As shown, the group I basalts reveal a covariance in plots of $\varepsilon_{\mathrm{Nd}}(\mathrm{T})$ vs. $(\mathrm{Ce} / \mathrm{Yb})_{\mathrm{N}}$, whereas $\mathrm{Ce} / \mathrm{Yb}$ ratios are nearly constant for the group II basalts within the $\varepsilon_{\mathrm{Nd}}(\mathrm{T})$ range of +5 to -5 (Fig. 2C). This separation indicates that there must have been at least two distinct processes involved in the basalt generation. In both cases, the primary plume-derived melts can be represented by the least enriched picrite sample EM-79, the geochemical characteristics of which are comparable to those of some picrites from the Siberian Traps (Wooden et al., 1993) and the high-Mg Icelandic basalts (Elliott et al., 1991). We consider its $\varepsilon_{\mathrm{Nd}}(\mathrm{T})$ value of +4 to be indicative of the average isotope composition for the Emeishan plume head. This is supported by the associated basalts with similar elemental characteristics, which show coherent isotope ratios of $\varepsilon_{\mathrm{Nd}}(\mathrm{T})$ from +4 to +5 (Fig. 2 ). This coherency may be interpreted as a result of compositional mixing of partial melts from the plume head, which, following the dynamic mantle plume model of Campbell and Griffiths (1990), is made up of the deep plume source and overlying mantle materials entrained during its ascent.

Considering the upper continental crust to be a potential contaminant (Fig. 2C), the group II Emeishan basalts can be explained as products of combined crystal fractionation and crustal assimilation processes from the parental magmas. However, this explanation fails to satisfy the requirement of the group I basalts and picrites, which need a mixing component with low ${ }^{143} \mathrm{Nd} /$ ${ }^{144} \mathrm{Nd}$ and high ${ }^{87} \mathrm{Sr} /{ }^{86} \mathrm{Sr}$ ratios, strong enrichment in the light REEs and other very incompatible elements, and a mild $\mathrm{Nb}-\mathrm{Ta}$ depletion as well (Fig. 2). The broad similarity of elemental patterns between the enriched Emeishan picrites and olivine lamproites from Western Australia (Fig. 3) implies that the component may be a lamproitic melt derived from a continental lithospheric mantle source (Nelson et al., 1986; Jaques et al., 1989). Lamproitic rocks commonly have high $\mathrm{Mg}$ numbers and very low abundances of $\mathrm{Al}_{2} \mathrm{O}_{3}, \mathrm{CaO}, \mathrm{Y}$, and heavy REEs, characteristics also revealed by the picrite samples (Table 1). Consequently, we propose that the Emeishan picrites were formed by mixing of two end members: these are (1) the large amount of liquid caused by decompression melting of the plume head, and (2) the small-volume lamproitic melt derived from the lithospheric mantle. If Western Australian olivine lamproites are taken to represent the latter, the most enriched Emeishan picrite can be generated by a 9:1 mixing of the two proposed components. The incorporation of $\sim 10 \%$ lamproitic melt accounts for not only the drastic enrichment of the very incompatible elements but also the minor $\mathrm{Nb}$-Ta depletion (Fig. 3).

Our model may encounter some difficulties in regard to melting of the mantle lithosphere beneath continents, as argued by Arndt and Christensen (1992), because the lithospheric mantle is generally considered to be refractory and cold, $\sim 300^{\circ} \mathrm{C}$ below its melting point at a given depth. However, this can be circumvented if the continental lithospheric mantle source region has undergone hydrous metasomatism. Metasomatized mantle peridotites may accommodate small amounts of water, which would significantly lower their solidus temperature and probably induce dehydration melting (Gallagher and Hawkesworth, 1992). We 


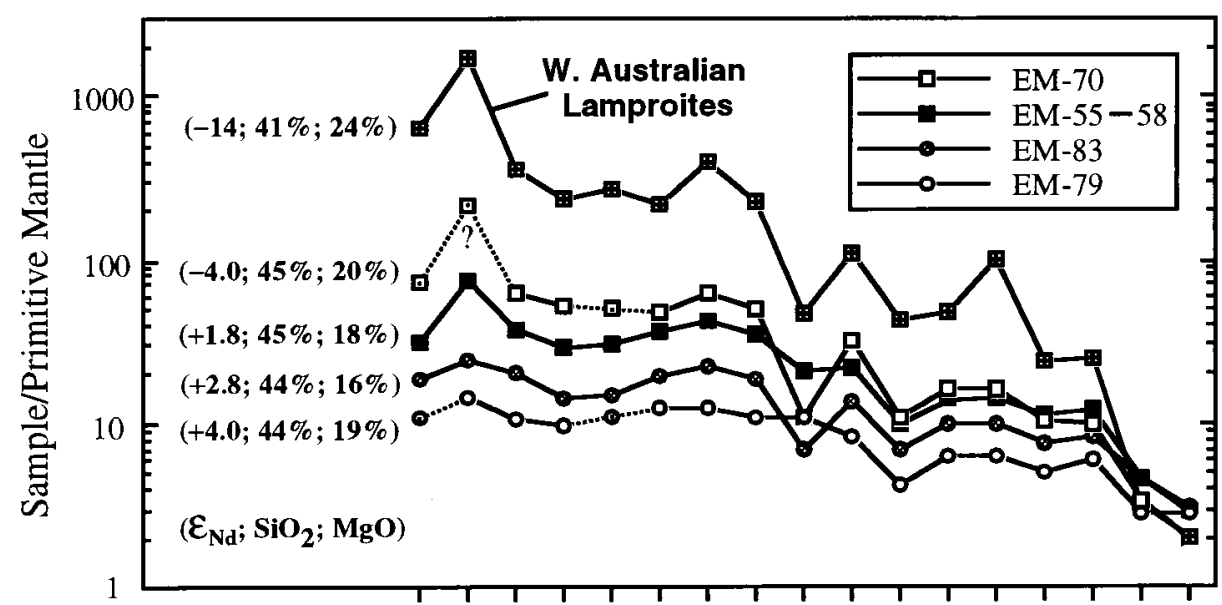

Rb Ba Th U K Nb La Ce Sr Nd P Sm Zr Eu Ti Y Yb

Figure 3. Primitive-mantle normalized diagram for Emeishan picrites and olivine lamproites from Western Australia (Jaques et al., 1989). Average composition of samples EM-55-EM-58 from one single flow is plotted. For reference, $\varepsilon_{\mathrm{Nd}}(\mathrm{T})$ values and $\mathrm{SiO}_{2}$ and $\mathrm{MgO}$ contents are also given. Alteration is suggested to have resulted in change of concentrations of mobile elements, such as loss of $\mathbf{R b}$ and $K$ in sample EM-70. However, it may also cause addition of $R b$ and $K$ because of formation of secondary micas in EM-79. In both cases, Rb and $K$ abundances are simply illustrated by extrapolation (Rb) and interpolation (K). Ba spike of sample EM-70 is hypothesized by mimicking that of samples EM-55-EM-58. Normalizing values of primitive mantle are from Sun and McDonough (1989).

believe that the lower part of the metasomatized lithospheric mantle, if thermally reactivated, can be a suitable source for the generation of lamproitic melts, which in turn may serve as a contaminant to the plumederived magmas (Ellam and Cox, 1991; Saunders et al., 1992).

\section{CONCLUSIONS}

The Emeishan basalt province is considered to have resulted from a starting mantle plume at the time of the Permian-Triassic boundary. The geochemical and isotopic evidence provided by the picrites studied supports the idea that the lithospheric mantle can play an important role in continental flood volcanism. The Karoo picrites are thought to have been produced by a similar process, i.e., plume-derived magmas mixed by lamproitic melts of lithospheric mantle origin in even greater (up to $50 \%$ ) proportions (Ellam et al., 1992). Nevertheless, alternative models are necessary to reconcile the wide range of geochemical data for other continental LIPs (cf. Saunders et al., 1992). Future studies of different rock types in the Emeishan province, particularly the alkalic rocks emplaced before the massive basalt eruptions (Huang, 1986), should better demonstrate the complexity of plumelithosphere interaction in continental flood magmatism.

\section{ACKNOWLEDGMENTS}

Chung received support from research grants from the National Science Council (Taiwan) and the Centre National de la Recherche Scientifique (France). We thank S.-s. Sun, G. Y. Wu, and B. L.
Cong for stimulating discussions and field guidance; G. L. Wang for help with instrumental neutron activation analyses; M. LeCoz-Bouhnik, O. Henin and J. Macé for assistance in X-ray fluorescence and isotope measurements; and $\mathrm{M}$. F. Coffin, R. A. Duncan, D. Geist, and W. F. McDonough for helpful reviews.

\section{REFERENCES CITED}

Arndt, N. T., and Christensen, U., 1992, The role of lithospheric mantle in continental flood volcanism: Thermal and geochemical constraints: Journal of Geophysical Research, v. 97 , p. $10,967-10,981$.

Campbell, I. H., and Griffiths, R. W., 1990, Implications of mantle plume structure for the evolution of flood basalts: Earth and Planetary Science Letters, v. 99, p. 79-93.

Campbell, I. H., Czamanske, G. K., Fedorenko, V. A., Hill, R. I., and Stepanov, V., 1992, Synchronism of the Siberian Traps and the Permian-Triassic boundary: Science, v. 258, p. $1760-1763$.

Chung, S. L., and Jahn, B. M., 1993, The PermoTriassic Emeishan flood basalts in SW China: Terra Nova, v. 5, Abstracts Supplement 1, p. 424.

Chung, S. L., Lin, L. H., Lo, C. H., and Jahn, B. M., 1995, Origin of the Emeishan flood volcanism in South China and its connection with the Permo-Triassic mass extinction [abs.]: International Union of Geology and Geophysics, 21st General Assembly, Proceedings.

Claoué-Long, J. C., Zhang, Z., Ma, G., and Du, S., 1991, The age of Permian-Triassic boundary: Earth and Planetary Science Letters, v. 105, p. $182-190$.

Coffin, M. F., and Eldholm, O., 1994, Large igneous provinces: Crustal structure, dimensions, and external consequences: Reviews of Geophysics, v. 32, p. 1-36.

Ellam, R. M., and Cox, K. G., 1991, An interpretation of Karoo picrite basalts in terms of interaction between asthenospheric magmas and the mantle lithosphere: Earth and Planetary Science Letters, v. 105, p. 330-342.

Ellam, R. M., Carlson, R. W., and Shirey, S. B., 1992, Evidence from Re-Os isotopes for plume-lithosphere mixing in Karoo flood basalt genesis: Nature, v. 359, p. 718-721.

Elliott, T. R., Hawkesworth, C. J., and Grönvold, K., 1991, Dynamic melting of the Iceland plume: Nature, v. 351, p. 201-206.

Gallagher, K., and Hawkesworth, C. J., 1992, Dehydration melting and the generation of continental flood basalts: Nature, v. 358 , p. $57-59$.

Huang, K. N., 1986, The petrological and geochemical characteristics of the Emeishan basalts from SW China and the tectonic setting of their formation [Ph.D. thesis]: Beijing, Institute of Geology, Academia Sinica (in Chinese).

Huang, K. N., Opdyke, N. D., Peng, X. J., and Li, J. G., 1992, Paleomagnetic results from the Upper Permian of the eastern Qiangtang Terrane of Tibet and their tectonic implications: Earth and Planetary Science Letters, v. 111, p. $1-10$

Jaques, A. L., Sun, S.-s., and Chappell, B. W., 1989, Geochemistry of the Argyle (AK1) lamproite pipe, Western Australia, in Ross, J., et al., eds., Kimberlites and related rocks: Geological Society of Australia Special Publication 14, p. 170-188.

McKenzie, D., and Bickle, M. J., 1988, The volume and composition of melt generated by extension of the lithosphere: Journal of Petrology, v. 29, p. 625-679.

Nelson, D. R., McCulloch, M. T., and Sun, S.-s., 1986, The origin of ultrapotassic rocks as inferred from $\mathrm{Sr}, \mathrm{Nd}$ and $\mathrm{Pb}$ isotopes: Geochimica et Cosmochimica Acta, v. 50, p. 231-245.

Richards, M. A., Duncan, R. A., and Courtillot, V. E., 1989, Flood basalts and hot-spot tracks: Plume heads and tails: Science, v. 246, p. 103-107.

Roeder, P. L., and Emslie, R. F., 1970, Olivineliquid equilibrium: Contributions to Mineralogy and Petrology, v. 29, p. 275-289.

Saunders, A. D., Storey, M., Kent, R. W., and Norry, M. J., 1992, Consequences of plumelithosphere interactions, in Storey, B. C., et al., eds., Magmatism and the causes of continental break-up: Geological Society of London Special Publication 68, p. 41-60.

Sun, S.-s., and McDonough, W. F., 1989, Chemical and isotopic systematics of oceanic basalts: Implications for mantle composition and processes, in Saunders, A. D., and Norry, M. J., eds., Magmatism in the ocean basins: Geological Society of London Special Publication 42 , p. 313-345.

Taylor, S. R., and McLennan, S. M., 1985, The continental crust: Its composition and evolution: Oxford, United Kingdom, Blackwell, $312 \mathrm{p}$.

Wooden, J. L., and eight others, 1993, Isotope and trace-element characterization of the Siberian continental flood basalts of the Noril'sk area: Geochimica et Cosmochimica Acta v. 57 , p. $3677-3704$.

Manuscript received March 8, 1995

Revised manuscript received June 12, 1995

Manuscript accepted July 7, 1995 